\title{
Occurrence of arsenic in agricultural soils from the Chaco-Pampean plain (Argentina)
}

\author{
C.V. Alvarez Gonçalvez ${ }^{1,2,3}$, F.E. Arellano ${ }^{1,2,3}$, A. Fernández Cirelli ${ }^{1,2,3}$ \& A.L. Pérez Carrera ${ }^{1,2,3}$ \\ ${ }^{1}$ Instituto de Investigaciones en Producción Animal UBA-CONICET (INPA), CONICET - Universidad de Buenos \\ Aires, Buenos Aires, Argentina \\ ${ }^{2}$ Universidad de Buenos Aires. Centro de Estudios Transdisciplinarios del Agua (CETA), Universidad de Buenos \\ Aires, Buenos Aires, Argentina \\ ${ }^{3}$ Universidad de Buenos Aires. Cátedra de Química Orgánica de Biomoléculas, Universidad de Buenos Aires, \\ Buenos Aires, Argentina
}

\begin{abstract}
Arsenic pollution is naturally present in groundwater and soils of the main agriculture production area of Argentine. Arsenic in soils, can be taken up and bioaccumulated in plant, and may be bio-transferred to agri-food and humans. All samples collected shown values between 18.6 and $33.1 \mathrm{mg} \mathrm{kg}^{-1}$ of total As. Range percentage of organic matter in analyzed samples were from 6.7 to $24.9 \%$. No significant correlation $(p>0.05)$ between total As level and organic matter was found. The As concentration in the analyzed samples were above the limits considered in Argentine. However, all samples were into the range previously reported by other authors.
\end{abstract}

\section{INTRODUCTION}

Arsenic (As) pollution affects several countries around the world. One of the most affected countries is Argentina, where As is naturally present in groundwater and soils of the main agriculture production areas (Bundschuh et al., 2012). It is known that presence of As in soils has an adverse impact on ecosystems (Bhattacharya et al., 2007; Huang, 2016). Arsenic in soils, can be taken up and bioaccumulated in plants. Also, livestock intake As from environmental matrices and food. Thereby, from animal and plant tissues, As may be bio-transferred to agri-food and humans, which implicates a potential risk to health.

Furthermore, it is known that organic matter present in soils affects the mobility of As species in the environment, being able enhance the release of As from soils facilitating As leaching into the groundwater (Wang \& Mulligan, 2006), and increasing their bioavailability (Huang et al., 2006).

The aim of this study is to assess total arsenic level in agricultural soils destined to fodder implantation, and further analyze the relationship between arsenic levels in soil and the organic matter present in the soil.

\section{MATERIAL AND METHODS}

\subsection{Study area and sampling}

This study was carried out in the Pampean Plain (Argentina). The study area is one of the most important livestock production regions. The samples zones are located in the west of Buenos Aires province and in the southeast of Cordoba province.

Thirty fodders fields from medium size farms were taken account for this study. For a preliminary analysis 14 samples were random select. All samples were collected from in plastic bags. In all cases soils samples were taken up from areas destined to the implantation of fodder and correspond to surface soil $(0$ to $20 \mathrm{~cm}$ underground). In each farm, samples were collected along transect in the field at regular intervals. Soil portions were mixed into the plastic bag, and were kept in the dark and refrigerated to $4^{\circ} \mathrm{C}$ until analysis.

\subsection{Chemical analysis}

Organic matter percentage was determinate by gravimetric procedures. Arsenic determination was according ISO 11466 (1995), soils were digested using a mixture of nitric acid and hydrochloric acid (1:3) at $120^{\circ} \mathrm{C}$ during $2 \mathrm{~h}$ with reflux. Arsenic was determined by emission spectroscopy in an inductively coupled plasma optical emission spectrometer (ICP-OES, Optima 2000, Perkin Elmer).

\section{RESULTS AND DISCUSSION}

\subsection{Arsenic level in soils}

Usually, arsenic in soils is 1 to $40 \mathrm{mg} \mathrm{kg}^{-1}$ (Kabata \& Pendias, 1992). Canadian Council of Ministers of the Environment (2001), considered in the Soil Quality Guideline for Environmental Health $\left(\mathrm{SQG}_{\mathrm{E}}\right)$ 


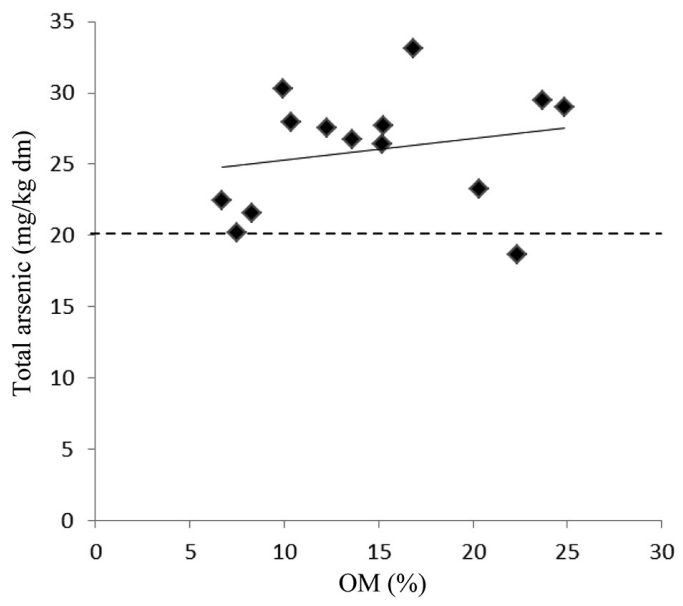

Figure 1. Relationship between total As ( $\mathrm{mg} \mathrm{kg}^{-1}$ dry mass) and organic matter percentage (OM\%) in soil samples. Continued line represents correlation between them. Dotted line represents maximum recommended level $\left(20 \mathrm{mg} \mathrm{kg}^{-1}\right)$ to total arsenic in soils destined to agricultural activities in Argentina.

for agricultural soil a maximum level of $17 \mathrm{mg} \mathrm{kg}^{-1}$ for inorganic arsenic. Recommended values for total arsenic content in agricultural soils in Argentina is $20 \mathrm{mg} \mathrm{kg}^{-1}$ (Ley 24.051, Decreto 831/93). All samples analyzed shown values between 18.6 and $33.1 \mathrm{mg} \mathrm{kg}^{-1}$ of total As, with a mean \pm standard deviation (SD) of $26.0 \pm 4.2$. Taking on account the recommended values for total As in Argentina, it was observed that 93\% of samples exceeded this guideline.

\subsection{Total As level and organic matter}

Relationship between total As level and organic matter amount was assessed. Range percentages of organic matter in analyzed samples were from 6.7 to $24.9 \%$ with a mean $\pm \mathrm{SD}$ of $14.8 \pm 6.1$. No significant correlation $(\mathrm{p}>0.05)$ between total As level and organic matter was found (Fig. 1).

\section{CONCLUSIONS}

The total As concentration in the analyzed samples were above the limits considered in Argentine. However, all samples were into the range previously reported by other authors. Therefore, it is necessary to determine the As species and its bioavailability present in those soils to evaluate the potential risk from the extensive use of this matrix.

On the other hand, organic matter from the first layer did not show evidence of correlation with As. Thus, to evaluate the organic matter effect in As mobility, it is suggested to evaluate the interaction of As with lower layers of soil.

\section{ACKNOWLEDGEMENTS}

The authors are grateful to the University of Buenos Aires and CONICET for financial support.

\section{REFERENCES}

Bhattacharya, P., Welch, A.H., Stollenwerk, K.G., McLaughlin, M.J., Bundschuh, J. \& Panaullah, G. 2007. Arsenic in the environment: biology and chemistry. Sci. Tot. Environ. 379: 109-120.

Bundschuh, J., Litter, M.I., Parvez, F., Román-Ross, G., Nicolli, H.B., Jean, J.S., Liu, C.W., López, D., Armienta, M.A., Guilherme, L.R.G., Cuevas, A.G., Cornejo, L., Cumbal, L. \& Toujaguez, R. 2012. One century of arsenic exposure in Latin America: a review of history and occurrence from 14 countries. Sci. Tot. Environ. 429: 2-35.

Canadian Council of Ministers of the Environment. 2001. Canadian Soil Quality Guidelines for the Protection of Environmental and Human Health: Arsenic (inorganic) (1997). Updated In: Canadian Environmental quality guidelines, 1999. Canadian Council of Ministers of the Environment, Winnipeg.

Decreto 831/93. Decreto Reglamentario de la ley 24.051 . Argentina.

Huang, J.H. 2016. Arsenic trophodynamics along the food chain/web of different ecosystems: a review. Chem. Ecol. 32(9): 803-823.

Huang, R.Q., Gao, S.F., Wang, W.L., Staunton, S. \& Wang G. 2006. Soil arsenic availability and transfer of soil arsenic to crops in suburban areas in Fujian Province, southeast China. Sci. Tot. Environ. 15(2-3): 531-541.

ISO 11466. 1995. Soil Quality - Extraction of trace element soluble in aqua regia.

Kabata, P.A. \& Pendias, H. 1992. Trace elements in soils and plants. Second edition, CRC Press, Boca Raton, Ann Arbor, London, pp. 203-209.

Ley 24.051 Ley Nacional de Residuos Peligrosos. Argentina.

Wang, S. \& Mulligan, C.N. 2006. Effect of natural organic matter on arsenic release from soils and sediments into groundwater. Environ. Geochem. Health 28(3): 197-214. 